\title{
Review on Environmental and Social Impacts of Rural Household Traditional Biomass Energy Utilization
}

\author{
Umer Abdela \\ Madda Walabu University, Department of Environmental Science, Bale Robe, Ethiopia
}

\begin{abstract}
Biomass is the sum total of all organic material or living matter derived from plants and animals which includes forestry and forest products industry residues. Biomass accounts for about $11 \%$ of total primary energy consumed globally, more than other renewables and nuclear power together. Approximately half of the world's population and up to $90 \%$ of rural households in developing countries still rely on unprocessed biomass fuels in the form of wood, dung and crop residues. Therefore, this paper is sets out to review the environmental and social impacts of rural traditional biomass energy utilization and utilization trends globally, in developed and developing countries, by reviewing different written and published materials such as research findings and different reports. the findings of those reports related to the selected topic and objectives is organized from global to rural house hold traditional biomass energy utilization and environmental and social impacts to rural house hold utilization trends. The link between environmental degradation and biomass utilization is most commonly drawn through deforestation and the resulting consequences of the loss of forest cover: erosion, decreased biodiversity, desertification, decreased soil moisture and nutrient loss, and change in surface roughness and albedo, which changes the radiative balance of the affected landscape. Indoor air pollution is the biggest health risk after malnutrition, HIV/AIDS, lack of clean water and adequate sanitation in developing countries. In addition to severe public health risks, engaging in production processes limits time spent in primary and secondary school resulted for the low rates of education in charcoal-producing communities; Rural and poor women and children in many developing countries spend a significant portion of their time gathering and collecting wood fuel, crop residues and animal dung for use as cooking and space heating fuels this relates to the opportunity cost of the time spent collecting wood.
\end{abstract}

Keywords: environmental, health, impact ,social , Traditional biomass

DOI: $10.7176 / \mathrm{JETP} / 9-9-01$

Publication date: December $31^{\text {st }} 2019$

\section{Introduction}

Energy is one of the basic requirements in human life; most of the rural people do not have enough access to efficient and affordable energy resources. The vast majority of rural people are dependent on traditional fuels such as wood, dung and crop residues, often using primitive and inefficient technologies. This resource continues to dominate the rural energy supply, now and in the foreseeable future. The resource is fast diminishing and thus precipitating a growing demand supply imbalance. The continued dependence on traditional biomass is not without considerable environmental, social and health implications. There is drudgery as well as intensifying cases of indoor air pollution-related morbidity. Supply deficit further leads to women and girls having to travel longer distances to collect firewood or turn into using lower grade fuels, further impoverishing their health (Lydia 2008)

Energy for cooking usually constitutes $70 \%$ to $90 \%$ of total energy use in less industrialized countries (ESMAP, 2007). About 2.5 billion people in these countries rely on biomass fuels

According to the International Energy Agency, 2010, the total number of people relying on biomass fuels will increase from today's 2.4 billion to 2.7 billion by 2030 (Guta, 2012).

According to a World Bank report, indoor air pollution in developing countries is designated as one of the four most critical global environmental problems (Amare, 2006, Clancy, 2004).

In rural areas of Africa, a substantial portion of infants, children, and women is exposed to debilitating levels of indoor pollution caused by biomass fuel use, which has an inefficient combustion process and a very high particulate matter emission (Smith, 1993). WHO estimates 1.5 million premature deaths per year are directly attributable to indoor air pollution (IAP) from the use of solid fuels (Smith, 1993). using various types of traditional fuels for cooking purpose is not only harmful for health but also one of the major causes of environmental pollution and energy crisis (Suleiman and A. Asfaw, 2011). The poorest countries are severely deforested at rates approaching $95 \%$ and even $98 \%$; In Africa it is responsible for over $90 \%$ of the woody biomass harvested (ESMAP, 2007).

A study done in Ethiopia in 2012 showed that about $77 \%$ of annual biomass consumption in Ethiopia is met from fuel wood, animal dung (13\%) and crop residue (9\%). For more than $90 \%$ of the Ethiopian population, the only energy used for cooking is obtained from biomass, in which $99 \%$ is derived from fuel wood, charcoal, crop residue, and leaves, with fuel wood occupying the leading position (Amare,2006, Legros,et al 2009). 


\subsection{Objective of the review}

The objectives of the paper was to review the environmental, social impacts of rural traditional biomass energy utilization and utilization trends globally, in developed and developing countries

\section{Methods of organization}

The paper is organized by reviewing different written and published materials such as research findings, workshop reports, conferences, online internet and other reports. The findings of those reports related to the selected topic and objectives is organized from global to rural house hold traditional biomass energy utilization and environmental and social impacts to rural house hold utilization trends. The paper also organized in the way that it can introduce or shows about traditional biomass energy source and resource for rural households, global traditional biomass energy utilization patterns, rural household dependence and utilization trends in both developed and developing countries, then its environmental and social implications.

\section{Result of literature review \\ 3.1 Definition}

Biomass is defined as "the sum total of all organic material or living matter derived from plants and animals which includes forestry and forest products industry residues; agricultural residues (e.g. sugarcane bagasse, cereal husks, straws), urban organic wastes, wastes from food and agro-industries and animal wastes , animal dung, municipal solid wastes (Bhattacharya \& Kumar 2000, Seagar ,2005)

They are often divided into two main categories of biomass wastes (residues) and energy crops.

Biomass wastes or residues refer to the remaining biomass after harvesting and after processing.(OFRI, 2006,Johnson\& Calle,2007).

\subsection{Biomass resources and Sources of household biomass energy}

According to Bhattacharya \& Kumar 2000, Seagar, 2005, Agricultural residues contribute significantly to the biomass sector, which is about $46 \%$ of traditional biomass energy is supplied from major crop residues such as maize and wheat stalks. Large amount of residues are produced by soybean, peanut, cotton, etc.( NREL,1992,Liu et al.2007).

\subsubsection{Wood Residues}

Woody biomass is a major source of primary energy for the majority of the world's poor, in some African countries, over $95 \%$ of households depend on wood for cooking and heating and available in large quantities as a residue from forest-based industries (Johnson, 2007, NREL, 1992). It is a renewable form of energy, which can be produced within the country by utilizing local resources (FAO, 2009). The global fuel wood consumption is estimated to be about 1.3 X $109 \mathrm{~m} 3$ (during 1990) and is further projected to treble by 2020 (FAO, 1993).However, in the year 2005 global wood removal was over 3 billion $\mathrm{m} 3$ of which $40 \%$ was in the form of wood fuel (FAO, 2007).

The United Nations Conference on new and renewable source of energy in Nairobi reported that an approximately 2 billion people depend on wood fuel for domestic uses (Ishengoma and Nagoda, 1991),By 1990s woodfuel as a major energy source accounted for $90 \%$ of energy consumed for cooking and heating at households in the world (FAO, 1996). Rowe et al. (1992) estimated that nearly 3 billion people worldwide primarily depend on forests as their main energy source. According to Mangi ,(2011) finding, throughout the world, demand for wood fuel is increasing and the world's scene is changing rapidly. It was further reported by the author by referencing (FAO, 2007) the wood fuel consumption shortages increased from 499 million $\mathrm{m} 3$ to $661 \mathrm{~m} 3$ between the year 1990 and 2005 respectively in Africa, The most serious situation was identified in the arid zones (Ishengoma and Nagoda, 1991).

It has been stated by FAO (1998) that there would be woodfuel deficit of 1-billion $\mathrm{m} 3$ in the world where 500 million $\mathrm{m} 3$ of woodfuel deficit will be found in Africa, about $140 \mathrm{~m} 3$ in Latin America and 60 million $\mathrm{m} 3$ in other countries(Soussan, 1998).

In countries like Ethiopia and even oil-rich ones like Nigeria in Africa and Nepal in Asia woodfuel constitute over $75 \%$ of energy by use (Eckholm et al., 1996). On the other hand, in Sub Sahara Africa, bio energy accounts for an estimated $60 \%$ to $90 \%$ of the total energy use with the highest proportion being in the poorest countries and the household sectors

Wood energy sources are preferred by most of people because the supply is more secure, available, affordable quantities in local markets and it requires no initial expensive investments in cooking stoves and generally collected from natural forests, bushes, established trees woodlot and farm lands at the margins of the fields and this will remain the priorities of the most consumers of rural and urban areas in developing countries (Ishengoma and Nagoda, 1991),however, Sathaye and Meyers (1994) reported that there are also costs of obtaining fuelwood in terms of cash or time spent in gathering 


\subsubsection{Agricultural Residues}

As cited in NREL (1992) Agricultural residues are expected to contribute about 1\% of total recoverable biomass energy. During periods of high energy prices, crop residues were used extensively as farm fuels in grain drying and space heating applications, especially in the Midwest. According to Lydia (2008), Farm residue is used as a source of fuel particularly in areas where energy demand exceeds supply and in certain seasons when wood supplies are limiting accessible to the farmer as a source of energy, households use farm residues but their use is mainly in rural areas but also with less amount in urban households used for cooking, water heating, ironing , lighting, home business and Only few of households reported using wood waste comprising of wood shavings, sawdust, timber rejects, and off-cuts(Kamfor,2002)

\subsubsection{Animal Wastes}

Animal wastes like cow dung is used on a large scale in the rural areas and to some extent in the poorer sections of urban areas. Cow dung is not only a source of energy, it is also natural fertilizer, though it is a popular source of fuel in many areas and it is not an efficient fuel,

According to Alemu and Köhlin,(2008), In a country where there are imperfect markets and much risk, attempts to encourage dung use more as manure and less as fuel require knowledge of the determinants of these alternative uses of dung. Particularly in northern Ethiopian highlands, a significant quantity of dung is used by rural households as fuel and/or as manure with variations across households. Some studies have suggested a need for different alternative fuels so that households can use more dung as manure (Erkossa and Teklewold 2007), studies have argued that cooking habits and related cultural practices indicate the need to use both wood and dung at the same time, suggesting a complementarity between the two fuel types(Mekonnen ,1999).

\subsection{Global Traditional biomass energy consumption}

Biomass accounts for about $11 \%$ of total primary energy consumed globally and also by far the most significant among renewable energy sources, accounting for about $80 \%$ of renewables used (Johnson\& Calle, 2007).majority of biomass energy over $85 \%$ is consumed as solid fuels in traditional uses at low efficiencies for cooking, heating, and lighting and are more than two billion people that rely on traditional biomass fuels and have no access to modern energy services (UNDP, 2001).

According to Johnson\& Calle,(2007) report, by referencing (Kammen and Lew 2005) ,There are huge differences between the rural and urban populations when relying on biomass for cooking:

The average dependency rates reported for the total population of Africa, Asia and Latin America are approximately $50 \%$ which breaks down as $80 \%$ for rural populations and $20 \%$ for urban ones. On the other hand, Maes and Verbist (2012) with reference to Bailis et al. (2005), Estimate the firewood, dung and crop residues dependency in rural areas of SSA to be $94 \%$ compared with $41 \%$ in urban areas; charcoal accounts for $4 \%$ and $34 \%$ respectively. These numbers translate on a global scale to around 2.4 billion dependents, $90 \%$ of them in developing countries (Urmee and Gyamfi 2014). However, higher total numbers are also reported (Shrimali et al. (2011): 2.5 billion; Bailis et al. (2015): 2.8 billion; Jagger and Shively (2014): 3.0 billion).

According to Kaygusuz (2011), this number is going to increase in the future; Raman et al. (2013) reports that by 2030, an additional 200 million people will depend on traditional fuels.

Concerning the overall quantity consumed, (WHO,2006) estimates based on 2.4 billion dependents that globally two million tonnes of biomass are consumed for cooking purposes on a daily basis. Kammen (1995) reports that $50 \%$ of the $3.0 \mathrm{Gt}$ of wood annually harvested are used as fuel (4.1 million t/day). Adkins et al. (2010) report, with focus on SSA, that "generally accepted values for household biomass use for cooking range from 2.5 to 3.0 tonnes per year". Similarly, Bailis et al. (2015) calculate the global woodfuel demand for 2009 with $1.36 \mathrm{Gt}$ (3.7 million t/day) and Jeuland and Pattanayak (2012) report that burning biomass (and coal) in traditional inefficient household stoves represents $15 \%$ of global energy use.

Bailis et al. (2015), on the other hand, outline that the share of the global wood harvest consumed as fuel equals $9 \%$ of global primary energy consumption; Iiyama et al. (2014) report 10\% respectively for "solid biomass".

In SSA, particularly charcoal but also firewood production and consumption have been reported to grow constantly in the last decades (Steierer 2011) and will do so in the decades to come (Arnold et al. 2006),Africa currently produces about half of the world's Charcoal (Kshirsagar and Kalamkar 2014). Iiyama et al. (2014) report the average annual growth rates of firewood and charcoal consumption between 2000 and 2010 in SSA to be 1\% and $3 \%$ respectively, the latter being higher than the average annual population growth rate of $2.6 \%$.

According to Gerland ,(2014) and UN,(2013b), One reason for the increased demand is the sharp population growth in SSA where the current population of about 1 billion is projected to reach between 3.1 and 5.7 billion by the end of the century as especially the population growth rate between 2050 and 2100 will surpass that of the world. Additionally, Mwampamba et al.(2013) another one is urbanization as this process is associated with a switch from the consumption of firewood to the more resource-consuming charcoal. Hosier et al. (1993) claim, with special reference to charcoal consumption, that a $14 \%$ increase is associated with a rise in the urbanization level of $1 \%$. Ncube (2012) reports African urbanization growth levels to be 3.5\% annually since 1990 with constant 
growth rates projected until 2050. However, strong regional disparities are reported even on the sub-national level (Potts,2009).

\subsection{Traditional biomass energy consumption in Industrialized and developing Countries}

Industrialized countries record significantly lower levels of biomass energy supply, most of which is modern biomass energy use so the share of biomass in total primary energy supply estimated at $3 \%$ in 2001 , an increase of 1\% since 1971 (IEA, 2003). The bulk of biomass energy use in industrialized countries comprises of modern biomass energy technologies (IEA, 2001; IEA, 2002). Accordingly biomass energy contributed about $2 \%$ of fuels used for electricity generation in 2001 (IEA, 2003). It was also predicted to increase in the future, although its contribution to final energy consumption will not substantially grow (IEA, 1998), additionally IEA, (2001) estimated it to increase from $1.6 \%$ in 1997 to $2.1 \%$ in 2020 .

In developing countries the proportion of biomass energy in the national energy mix is even much higher (Ezzati, et al.2002, Kambewa and Chiwaula 2010; Mugo and Gathui 2010; Ng'andwe and Ncube 2011). E.g Malawi (97\%), Kenya ( $68 \%$ ), Zambia (74\% ) of their total primary energy supply.

In most rural communities in Sub Saharan Africa (SSA), poverty can mean, among other things, having to rely primarily on wood and/ or dung for cooking, heating and lighting (Dzioubinski \& Chipman 1999). Urmee and Gyamfi (2014) and Sosovele (2010) outlined as the dependency is highest in SSA, Indonesia, India and the rest of Asia with respective rates between $60 \%$ and $80 \%$ if the total population is considered Traditional fuels are and will for the foreseeable future remain by far the dominant cooking energy sources in developing countries (Kees and Feldmann 2011, Raman et al. 2013,Iiyama et al. 2014).

\subsection{Household traditional biomass energy consumption trends}

Apart from households, there are many bulk users of firewood including learning institutions, prisons, industries such as tobacco, tea curing and fish smoking, and small and medium enterprises such as restaurants and camping sites. Most of them use wood-fired steam boilers to generate heat in order to reduce the cost of tea production (Githiomi and Oduor. 2012).Firewood plays important role in meeting energy needs in many countries and not simply view it in terms of negative environmental impacts. Average per capita household energy use in developed countries is about nine times higher than in developing countries, even though in developing countries. A large share of the most notable trend is the decline in per capita household energy consumption in North America, which in 1970 had much higher household energy consumption than any other region. The difference remains considerable but it decreased substantially. This decline is a result of several factors, including increased energy efficiency and saturation with domestic electrical appliances (Dzioubinski \& Chipman ,1999).

\subsection{Household Income and the Energy ladder}

Biomass energy use is dependent on various factors, such as geographical location, land use patterns, preferences, cultural, social issues and income distribution patterns also contribute to variations in biomass energy use, with poorer regions relying on traditional forms of biomass, and industrialized regions using more modern biomass energy technologies (Leach, 1992).

The major factors contributing to these differences are levels of urbanization, economic development, and living standards, region specific factors, such as climate or cultural practices Household energy consumption is expected to increase in future along with growth in economy and rise in per capita incomes(Sathaye and Meyers, 1985, Leach,1992 and World Bank, 2000).

According to Pachuri, (2004), the projected increases in household energy consumption are expected to result from changes in lifestyles

\section{Environmental Impacts of Traditional Biomass Use as Energy}

The current extraction and consumption pattern of biomass has led to forest degradation and deforestation, loss of biodiversity, soil degradation, atmospheric pollution and indoor air pollution leading to domestic health hazards and loss of nutrients due to combustion of cattle dung and crop residues.

\subsection{Deforestation and Land Degradation}

Biomass comprising traditional fuels constitutes about $50 \%$ of energy consumption in developing countries, however according to (Kaale, 1990),In the case of some countries like Bangladesh, Ethiopia, Burkina Faso, Malawi, Tanzania, and Uganda it is estimated to be as high as $90 \%$. The effects of this traditional energy carrier dependency on forest degradation and deforestation have been controversial over the last few decades, with the discussions meandering between call for immediate global action to the necessity of narrower location and time specific analyses (Hiemstra-vander Horst and Hovorka 2009, Maes and Verbist 2012, Mwampamba et al. 2013, Bailis et al. 2015).

Iiyama et al. (2014) outlined that "displacement for agriculture appears to be the most important driver for 
deforestation in humid forest areas and charcoal often a byproduct of forest clearance. Chidumayo and Gumbo (2013) attributed 33\% of deforestation in Tanzania to charcoal production according to their calculation which is a world record. Mwampamba (2007), perceives the attribution of charcoal production in deforestation in Tanzania as between 30-60\%; Makundi (2001) believes that 70\% of Tanzanian forest loss due to woodfuel consumption $43 \%$ due to direct removals could be realistic. Msuya et al. (2011) concludes that "more forest will be cut to fulfill the demanded charcoal.With reference to the effects of charcoal and firewood production and use, a recent review points out that deforestation or, more frequently, degradation of forest "may occur or not" at the local level depending on the specific context (Mandelli et al. 2014).

In some countries (Tanzania), there is evidence that firewood collection rarely represents a threat to forests (Mwampamba 2007) while the effects of charcoal production seem to be quite different (Chidumayo and Gumbo 2013). However, Mwampamba et al. (2013) perceive the common knowledge about direct links between charcoal and deforestation to be a myth while Gmünder et al. (2014) highlight that charcoal production leads not to land use change but to temporal deforestation only, however, constant and increasing pressure on forest resources will inevitably lead to deforestation and subsequently (top) soil erosion and exhaustion (Campbell et al. 2003).

Other researchers perceive knowledge gaps to be only marginal by outlining that the impact of woodfuel consumption is well documented (Murphy 2001) while Hartter and Boston (2007) simply state that "in the end, human daily caloric intake is what drives fuelwood consumption and ultimately the loss of natural forest."

There are divergent views on the contribution of fuelwood extraction to deforestation ranging from a marginal (such as in India) to a significant factor (for charcoal production in Africa for domestic use and as industrial fuel in Brazil). The Studies by (Ravindranath and Hall, 1995) have concluded that fuelwood extraction contributes at varying degrees to loss of trees (in villages and forests), forest degradation and ultimately to deforestation.

Deforestation leading to soil erosion, risks of floods, desertification on account of clearing of forests and woodlands for agriculture and livestock, and so on, are the common concerns of environmentalists at macro levels. At a micro level, the concerns range from non-suitability of forest soils for agricultural purposes, health problems due to smoke caused by burning of fuelwood, loss in soil fertility due to use of agricultural residues and so on. Even a shift towards non-wood biomass fuels creates direct competition with animals that rely upon crop residue and the shrubs for fodder (Kaale,1990).

The environmental impacts of urban fuel wood consumption have been severe due to commercial exploitation of fuel wood for charcoal production. The demand for charcoal in urban areas has spread deforestation, which begins at the surrounding areas of urban centers and moving outwards (Ravindranath and Hall, 1995).As referenced by Johnson,(2007), UNDP, (2004) described Unsustainable extraction practices of forest and wood products industries are a major source of environmental degradation in many regions. As cited in (Ravindranath and Hall, 1995) added the imbalance between the demand and production of fuelwood is reported to be one of the primary factors responsible for forest depletion. The increasing use of fuelwood for meeting the domestic and industrial needs of both rural and urban areas has contributed to forest decline.

Reliance on traditional biomass (especially in the form of charcoal) contributes to land degradation (Scully, 2002) and deforestation in countries where charcoal (sourced from natural forests and not planted forests) is widely used.The unreliability of biomass energy data complicates attempts to link deforestation to biomass use but the consensus among leading biomass energy experts is that inefficient charcoal production from natural forests and woodlands contributes to deforestation (FAO/ADB, 1995).

In addition, charcoal production often leads to uncontrolled fires, which destroy biodiversity and contribute to regional air pollution (Stephen et al, 2004). In some areas charcoal demand appears to contribute to degradation of the surrounding woodlands and forests (Scully, 2002).Traditional charcoal production is a particularly inefficient process, resulting in significant loss of energy in the conversion of woodfuel to charcoal (Karekezi and Ranja,1997; IEA, 1998; Rosillo-Calle et al., 1995).

Impacts on the physical environment include immediately observable phenomena such as decreased tree cover or dramatic erosion events like slope failure, as well as long term impacts that may go unobserved for years or decades like slow loss of top soil, decreased soil fertility, loss of soil moisture, or loss of biodiversity(MoPD\&E, 2004).It is believed that the charcoal production is more severe than overgrazing as a cause of rangeland degradation, because acacia species which is an important fodder for goats and camels is more rapidly annihilated by charcoal producers than by over grazing. Traditional fuel production (charcoal) and consumption (firewood) that results in deforestation or forest degradation is a matter of scale: On a micro-scale, clear evidence can be found ( Luoga et al. (2000) while on a macro-scale, no clear evidence exists (Mandelli et al. 2014).

\subsubsection{Loss of biodiversity}

As referenced in (TERI, 2010) and (WWF, 2007) finding shows that depending on land type, cultivation forms (rotation scheme, plantation management plan, etc), there are threats of biodiversity loss and Conversion of forest land for bioenergy usage would lead to severe loss of biodiversity. Biomass energy feedstock production significantly influences surrounding ecosystems, enhancing or suppressing biodiversity and percentage of nationally recognized areas of high biodiversity value or critical ecosystems converted to bioenergy production 
and also area and percentage of the land used for bioenergy production where nationally recognized conservation methods are used(GBEP 2011). Some biomass use is non-selective while some use tends to be selective. For instance, charcoal makers tend to have preferred species. Hence as long as charcoal is being made, the preferred species become targeted and therefore endangering thepreferred species.According to Kambewa, and Chiwaula, (2010), Deforestation has impact on biodiversity depending on the use of the biomass. Kambewa et al. (2007) showed that the preferred species for charcoal production were still present as dominant or important species. However in other sites, different species had assumed dominance and importance implying that species composition was altering. However the absence of preferred species did not stop people from making charcoal ((Kambewa, and Chiwaula, 2010, Ngalande (Undated)).

\subsubsection{Impact on soil}

Agricultural residues constitute an important source of energy in rural areas of developing countries and when left on fields improves the fertility of the soil. The use of agricultural residues for energy would thus be an issue if it reduces the fertility of the soil and pose a particular challenge for good soil management because the plant material is often completely harvested, leaving little organic matter or plant nutrients for recycling back into the soil (Kartha, 2006).However, all residues do not have the same effect on the soil as some residues such as corncobs, rice husk, jute sticks, cotton stock, coffee pruning's, and coconut shells do not decompose easily and have potential as energy sources( Kambewa, and Chiwaula, 2010). As cited in Kambewa, and Chiwaula, 2010, Environmental impacts of biomass production must be viewed in comparison to the likely alternative land-use activities.

In many rural areas in the developing world where soil management depends on recycling crop wastes and manure rather than use of external inputs, biomass production could lead to dramatic declines in soil fertility and structure (cited in kartha, 2006). Soil quality Percentage of land for which soil quality, in particular in terms of soil organic carbon, is maintained or improved out of total land on which bioenergy feedstock is cultivated or harvested (GBEP 20011,WWF, 2007).

In many cases, farmers can reduce the risk of nutrient depletion by allowing the most nutrient-rich parts of the plant, small branches, twigs, and leaves to decompose on the field. Burning of cattle dung as fuel leads to loss of organic matter and other nutrients affecting crop production (Ravindranath and Hall 1995).

\subsubsection{Impact on atmosphere}

Combustion of fuelwood and other biomass fuels leads to $\mathrm{CO} 2$ emissions, as nearly $50 \%$ of wood is carbon. If fuelwood is coming from sustainable modes of extraction, its combustion will lead to no net $\mathrm{C}$ emission. However, it is difficult to estimate what percentage of fuelwood use is from non-sustainable source. Use of fuelwood as an energy source contribute to the accumulation of $\mathrm{CO} 2$, the main greenhouse gas, both because burning fuelwood produces CO2, and because deforestation destroys an important CO2 sink,( Oladosu and Adegbulugbe 1994, Dzioubinski \& Chipman 1999).

At a global level, about $2.8 \%$ of CO2 emission is attributed to fuelwood combustion (Ahuja, 1990). In addition to $\mathrm{CO} 2$ emissions, combustion of fuelwood and agro-residues leads to emission of products of incomplete combustion. These products are even more powerful GHGs per gram in carbon emitted than CO2 (IPCC 1992). An estimate of the global warming potential of non $\mathrm{CO} 2 \mathrm{GHGs}$, such as $\mathrm{CO}, \mathrm{CH} 4$ and non- methane hydro-carbons, could be in the range of $20-110 \%$ as much as that of CO2 itself, depending on the timeframe (Smith, 1991,GBEP 2001).

It is a common notion that burning biomass merely returns the $\mathrm{CO}$ that was absorbed as the plants grew and as long as the cycle of growth and harvest is sustained, biomass burning is carbon-neutral (Ravindranath and Balachandra, 2009) and burning biomass will not solve the currently unbalanced carbon dioxide problem. Conceptually, the carbon dioxide produced by biomass when it is burned will be sequestered evenly by plants growing to replace the fuel. In other words, it is a closed cycle which results in net zero impact. According to Kambewa et al. (2007) in countries where biomass is the major source of energy, one factor to be taken into account is the effect of biomass use on carbon sequestration as increased biomass use as a source of energy means that the country's ability to sequester carbon gets reduced.

\subsection{Social and health impacts of traditional biomass energy usage}

Rural and poor women and children in many developing countries spend a significant portion of their time gathering and collecting wood fuel, crop residues and animal dung for use as cooking and space heating fuels (Energia, 2001; Energia 2002; ITDG, 2003).A common impact from the use of wood fuels relates to the opportunity cost of the time spent collecting wood. The gathering of wood can require several hours per day, sometimes preventing children from attending school, and women from improving their livelihood by engaging in other, possibly profitable enterprises.

The challenging and tiring task of collecting firewood for household use is often the responsibility of women and children. This involves spending at least one day each week travelling long distances to the forest hence limited time to be involved in other more productive activities, and carrying heavy loads of firewood on their backs or heads, thus risking spinal, head and leg injuries . In addition, they are at risk of being attacked by wild animals and 
human beings. Young children involved in firewood collection often miss education opportunities, a situation that disproportionately affects girls (Nyambane et al, 2014).

\subsubsection{Education and Employment}

As Jones, (2015) citation by referencing other authors the common trend of gender inequality found in both urban and rural areas of developing countries. The largest impact of changes in biomass usage patterns at the household level will certainly be on women and children, who expend the greatest portion of effort on the acquisition of woodfuels and other biomass resources. The demand for biomass will almost certainly increase the monetary value of biomass, making it less available to both the poorest families, and to women (Kammen, 1995b).

In addition to severe public health risks, engaging in production processes limits time spent in primary and secondary school resulted for the low rates of education in charcoal-producing communities; the forecasted increase in charcoal demand in the coming years may expose more children to serious injury, while preventing them from engaging in educational activities, unless the social effects of energy are holistically considered in national policies (Jones, 2015) and there are further disparities related to education, employment and income generation among men and women.UNDP (2001) reports reveal that when women are overburdened, they are more likely to keep their daughters at home and away from school to assist with household activities, including fuel and water collection, thereby limiting opportunities for girls to move forward through education, thus increasing the likelihood that their families will remain in poverty.

\subsubsection{Gender related issues of Biomass fuel}

According to Lambrou and Laub, 2006, as cited in Lydia 2008 report, if biomass fuels production competes either directly or indirectly for water and firewood supplies, it could make such resources less readily available for household use. This would force women who are traditionally responsible, in most developing countries, for collecting water and firewood, to travel longer distances, reducing the time available to them to participate in decision-making processes and income generating pactivities.

The poor households not only use small amounts of energy, but also rely on lower quality fuels such as animal dung, agricultural waste and fuel wood. Reliance on these fuels limits the amount of service that can be obtained and affects gender adversely (Najam and Cleveland, 2003; Rouse, 2004). The developing countries not only show low level of development, but also high degree of inequality among men and women and there is an increasing shortage of fuelwood supply and this adds burden of fuel collection for Several hours a day are spent in collecting these fuels by women and children (Pachauri 2004). It means that this time cannot be used for other livelihood activities and also negatively affects children's learning by keeping them away from school.

Although nearly every household in rural areas uses some biomass as an energy carrier, poor households spend more time in collecting than those in higher income groups. The consequences for the poor are that precious time is used on collecting low quality fuels, which are then used at low efficiency, reducing their ability to accumulate the financial resources they need to invest in strategies for improving their livelihoods. According to some researches the low efficiency of utilization of biofuels damages people's quality of life and imposes enormous costs on the community (Reddy, 2004).

Energy activities influence the status of women and in turn get influenced by them. Access to clean energy services improve women's social, economic and political status, reducing the time and effort involved in household chores, providing better health and educational conditions, expanding income-generating opportunities, and easing their participation in public affairs(UNDP, 2006).

Gender inequalities in education, excess levels of female to male mortality and higher numbers of men to women in the overall population than is considered 'standard' is common in many societies (Kabeer, 2003). According to Lagerlöf (2003) gender equality contributed significantly to the economic development in Europe achieved for the past 2000 years. The importance of women as key drivers of development in environment and energy needs to get attention it deserves (UNDP, 2007).

Moreover, this family labor provided by women is unpaid and thereby it does not enter the market system and hence women are not credited for their true contributions. Since the time spent by women on these survival tasks is largely invisible, For example, while the energy used by an electric pump for water pumping can be easily measured and reported, the energy expended by a woman fetching water goes unmeasured, unmonetized and unrecorded in energy statistics. Trucks that transport fuels are a part of market mechanisms whereas the energy of women head-loading the same is excluded (Cecelski, 2000).

Cecelski, (2000) added at the extreme fuelwood scarcity, the responsibility of collecting fuelwood gradually shifts to children, who have no choice but to glean for any available stick wood on the roadsides. Ultimately, women are left juggling multiple roles most of which are contingent on the provision of energy. Moreover, the gender asymmetries and divisions of labor which have historical, societal and cultural roots have resulted in unequal and exacerbated impoverishment in the contemporary rural development arena.

\subsubsection{Biomass Energy and Health}

Indoor air pollution can be traced to prehistoric times when humans first moved to temperate climates and it became necessary to construct shelters and use fire inside them for cooking, warmth and light. Fire led to exposure 
to high levels of pollution, as evidenced by the soot found in prehistoric caves (Albalak .,1997). Sources of indoor air pollution in developing countries include smoke from nearby houses (Smith et al., 1994), the burning of forests, agricultural land and household waste, the use of kerosene lamps (McCracken \&Smith, 1998). Fires in open hearths and the smoke associated with them often have considerable practical value, for instance in insect control, lighting, the drying of food and fuel, and the flavoring of foods (Smith, 1987).

Use of biomass in traditional stoves exposes the users, mainly women and children, to high levels of indoor air pollution,( Oladosu and Adegbulugbe 1994, Dzioubinski\&Chipman 1999).According to the WHO, indoor air pollution is the biggest health risk after malnutrition, HIV/AIDS, lack of clean water and adequate sanitation in developing countries. It is estimated that 1.5 million die because of the effects of indoor air pollution from cooking each year. This translates into 4,000 deaths per day. In sub-Saharan Africa alone 396000 people, in particular women and children, reportedly died of indoor air pollution in 2002 (WHO, 2006,Nyambane et al ,2014,Ezatti, 2002).

According to the latest Global Burden of Disease estimates, use of biomass fuels is now the second leading risk factor for ill health in developing countries (Lim \&Vos . 2012) as biomass fuels Wood smoke contains hundreds of different compounds, The most important are particles, carbon monoxide, nitrous oxides, sulphur oxides (principally from coal), formaldehyde, and polycyclic organic matter (Koning,1985). Particles with diameters below 10 microns (PM10), and particularly those less than 2.5 microns in diameter (PM2.5), can penetrate deeply into the lungs and appear to have the greatest potential for damaging health (United States Environmental Protection Agency, 1997).

These particles penetrate deeply in the lungs and are thought to cause more health damage than larger particles (Raiyani et al., 1993, Bruce, et al., 2000).

People in developing countries are commonly exposed to very high levels of pollution for 3-7 hours daily over many years (Engel, 1998). During winter in cold and mountainous areas, exposure may occur over a substantial portion of each 24-hour period (Norboo et al, 1991), because of their customary involvement in cooking; women's exposure is much higher than men's (Behera, 1988).

A health effect is determined not just by the pollution level but also, and more importantly, by the time people spend breathing polluted air, i.e. the exposure level. Exposure refers to the concentration of pollution in the immediate breathing environment during a specified period of time (Lioy, 1990). The strongest evidence of causal linkage between biomass combustion emissions and ill health is with ARI in children (Smith, et al., 2000a; Ezzati and Kammen, 2001, Bruce et al. 2000). ARI is the primary cause of morbidity and mortality in children under five -causing more deaths and ill health than malnutrition, diarrhoea, or childhood diseases like measles and mumps. The WHO (1995) estimates that there were over 4 million ARI(Acute Respiratory Infection ) related deaths in 1993 among children under five, which is about $25 \%$ of all deaths in that age group.

Notwithstanding the significance of exposure to indoor air pollution and the increased risk of acute respiratory infections in childhood, chronic obstructive pulmonary disease and lung cancer (Smith ,1987, Chen et al,1990), the health effects have been somewhat neglected by the research community, donors and policy-makers.

Several studies have reported an association between exposure to biomass fuel smoke and general acute respiratory illness in children, mostly of the upper respiratory tract. Middle ear infection (otitis media) is rarely fatal but causes much morbidity, including deafness, and makes demands on the health system. Evidence from developing countries is very limited, but there is good reason to expect an association.

Pollution attributable to the use of biomass fuel causes eye irritation (Ellegard,1997) and may cause cataract. Acute lower respiratory infections are the single most important cause of mortality in children aged under 5 years, accounting for around 2 million deaths annually in this age group. Various studies in developing countries have reported on the association between exposure to indoor air pollution and acute lower respiratory infections (Collings et al,1990, Robin et al 1996, Kossove,1982-Morris et al.1990).

Societies which have emphasized on female health care and where there is a higher participation of women in education and workforce have evidenced higher economic growth and development (Nathan et al, 2009). It is also found that developed countries have shown reduced gender inequality and improved status of women which brings about greater macro-economic stability, whereas women's relative lack of opportunities in developing and least developed countries inhibits economic growth (Stotsky, 2006).

According to Laxmi et al, (2003) the health impacts of the use of bio-fuels are quite high for adult women, the losses incurred because of cooking fuels, including work days spent, expenditure on illness and lost working days due to illness are Rs. 29 billion per year in the rural areas of Rajasthan.

Smith (2000) has indicated that high risks such as respiratory infections (ARI), chronic obstructive pulmonary disease (COPD), lung cancer and also tuberculosis (TB), asthma, and blindness are prevalent in India on account of indoor air pollution As per World Health Organization (WHO), indoor air pollution which is referred to as killer in the kitchen' is responsible for 1.6 million deaths per year, i.e., one life is lost in every 20 seconds (UNDP, 2007). 


\section{Conclusions}

Energy is one of the basic requirements in human life; most of the rural people do not have enough access to efficient and affordable energy resources. The vast majority of rural people are dependent on traditional fuels such as wood, dung and crop residues, often using primitive and inefficient technologies. This resource continues to dominate the rural energy supply, now and in the foreseeable future. The resource is fast diminishing and thus precipitating a growing demand supply imbalance. The continued dependence on traditional biomass is not without considerable environmental, social and health implications.

The use of biomass for energy has effects on all the environmental media i.e. soil, water and air. In addition, these effects may have impacts on human and animal health and welfare, soil quality, water use, biodiversity and public amenity. With no choice but to satisfy household energy needs, both tree cover and soil quality are sacrificed, leaving rural households impoverished and often forcing some household members to seek wage employment in towns. The potential impact of fuel use on the environment, materials of economic values such as cow dung and crop residues are also diverted to fuel use instead of being used as fertilizer in crop production .wood fuel demand, threaten the land, through soil deterioration, water base, and consequently degrade the environment.

Traditional biomass energy (wood, dung, crop residues) is associated with indoor air pollution and its increasing shortage causes drudgery to women owing to their traditional role as providers of household energy. There is mounting evidence that the resulting air pollution increases common, serious health problems, including childhood pneumonia and chronic lung disease. women and children are the main victims to IAP health outcomes since they stay longer near fireplaces cooking, more exposed to biomass based indoor air pollution.

Rural households depend on traditional sources of energy, as their income level is very low and lack of purchasing capacity, majority of households do not afford to buy fuel for their day-to-day use. Vast unemployment and acute poverty forces the rural poor to go on hunting for fuel. Small children of the age of 8 years and above also go to the forests or nearby grazing land, fallow land, and waste land in search of fuel. Men, Women and children, on an average daily spend about $3 \mathrm{hrs}$ in fuel gathering and they walk about 4 to 5 kilometers in search of fuel wood.

An increase in per capita income leads to an increase in the quantity of energy demand. Income increase, significantly influences the consumption pattern as:" People shift their demand from inferior type of fuel to superior type of fuel

\section{The way forward}

The people of rural household should be able to afford and access alternative sources of energy rather than fuel wood to reduce deforestation, promote afforestation and improve the environment. Besides, the entire region should give more emphasis in exploiting its potentials in renewable energy such as solar, wind and biogas for sustainable development.

Greater access to modern energy services can provide significant social, economic and psychological benefits, especially for women and girls in developing countries, who are the primary providers and users of traditional fuels such as wood, dung and charcoal.

The amount of agricultural residues that is removed for energy must be balanced with the need for soil amendment, erosion control and appropriate methods of stubble management have to focus on dry land agriculture and retaining residues for erosion control should give priority for soil conservation and rangeland management.

Firewood collection and use is a traditional activity that has received relatively limited attention from researchers, development practitioners, development partners (donors) and policy makers. This has led to a general lack of knowledge on how to move to more sustainable practices associated with the use of firewood.

Farmers knowledge on farm planning such as where, how and which species of trees to plant on their farms and how to harvest firewood from these trees should be improved and promoted.

Researchers and project implementers should contribute in Mapping of woodfuel multipurpose tree species for different ecological zones and involvement of end users in development of technologies aimed at energy use efficiency such as improved firewood cookstoves

Policy makers should provide Scalable data on good practices as well as funding and enforcement of existing bioenergy policies and regulations.

The contribution of firewood to welfare and economic activities in the country is enormous and it should be directly addressed under the energy policy. All of the county's governments should play a vital role as the key initiators in the realization of a sustainable firewood production and use system, through a multi-sectoral integrated approach. These recommendations can be achieved, through:

- Development of plantations for woodfuel,

- Adoption of on-farm tree planting (agroforestry) with proper management and appropriate choice of tree species

- Efficient management of forests and dry lands

- Development and adoption of efficient firewood cook stoves (cookstove manufacturers and firewood users) 
- Development and adoption of innovative technologies for supply of cheaper and cleaner cooking fuel such as gasification and briquetting of biomass (cook stove manufacturers and biomass users)

- Enabling institutional and legal framework on wood fuel (policy makers)

- Awareness creation to ensure each player recognizes the value of a particular practice (all stakeholders in the firewood chain

\section{References}

Adkins, E., Tyler, E., Wang, J., Siriri, D. and Modi, V., 2010. Field testing and survey evaluation of household biomass cookstoves in rural sub-Saharan Africa. Energy for sustainable development, 14(3), pp.172-185.

Albalak, R., 1997. Cultural practices and exposure to particulate pollution from indoor biomass cooking: Effects on respiratory health and nutritional status among the Aymara Indians of the Bolivian highlands (Doctoral dissertation).

Bailis, R., Ezzati, M. and Kammen, D.M., 2005. Mortality and greenhouse gas impacts of biomass and petroleum energy futures in Africa. Science, 308(5718), pp.98-103.

Behera, D., Dash, S. and Malik, S.K., 1988. Blood carboxyhaemoglobin levels following acute exposure to smoke of biomass fuel. The Indian journal of medical research, 88, p.522.

Bhattacharya, S.C. and Kumar, S., 1997. Renewable energy technologies in Asia: a review of current status.

Bruce, N., Perez-Padilla, R. and Albalak, R., 2000. Indoor air pollution in developing countries: a major environmental and public health challenge. Bulletin of the World Health organization, 78, pp.1078-1092.

Campbell, B.M., Vermeulen, S.J., Mangono, J.J. and Mabugu, R., 2003. The energy transition in action: urban domestic fuel choices in a changing Zimbabwe. Energy Policy, 31(6), pp.553-562.

Chidumayo, E.N. and Gumbo, D.J., 2013. The environmental impacts of charcoal production in tropical ecosystems of the world: A synthesis. Energy for Sustainable Development, 17(2), pp.86-94.

Clancy, J., Maduka, O. and Lumampao, F., 2008. Sustainable energy systems and the urban poor: Nigeria, Brazil, and the Philippines. In Urban Energy Transition (pp. 533-562). Elsevier.

Collings, D.A., Sithole, S.D. and Martin, K.S., 1990. Indoor woodsmoke pollution causing lower respiratory disease in children. Tropical doctor, 20(4), pp.151-155.

de Koning, H.W., Smith, K.R. and Last, J.M., 1985. Biomass fuel combustion and health. Bulletin of the World Health Organization, 63(1), p.11.

Desalegn, B., Suleiman, H. and Asfaw, A., 2011. Household fuel use and acute respiratory infections among younger children: an exposure assessment in Shebedino Wereda, Southern Ethiopia. African Journal of Health Sciences, 18(1-2), pp.31-36.

Eckholm, E., Foley, G., Barnard, G. and Timberlake, L., 1984. Fuelwood: the energy crisis that won't go away. Earthscan.

EIA.(1998) .Forest products industry brief.U.S. Department of Energy, Energy Information Administration.http:/www.eia.doe.gov/emeu/mecs/iab98/forest/intensity.html Ministry of Pastoral Development \& Environment.

Ellegård, A., 1997. Tears while cooking: an indicator of indoor air pollution and related health effects in developing countries. Environmental Research, 75(1), pp.12-22.

Erkossa, T. and Teklewold, H., 2007. Economics of Manure and Nitrogen Fertilization in Crop Rotation System. Debre Zeit Agricultural Research Centre, PO Box, 32.

ESMAP.( 2007). Energy Sector Management Assistance Program, "Strategy to Alleviate the Pressure of Fuel Demand on National Wood fuel Resources," Haiti,

Ezzati, M. and Kammen, D.M., 2002. Evaluating the health benefits of transitions in household energy technologies in Kenya. Energy policy, 30(10), pp.815-826.

FAO .(1996). Forest Resources Assessment: Survey of Tropical Forest Cover and Study of Change Processes. Forestry Paper No. 130. Rome, Italy. 141pp.

FAO .(2002). Global Forest Resource Assessment. FAO Paper No. 140. Rome, Italy. 103pp.

FAO. (1998). Interim Report on State of Forest Resources in Developing countries. Rome, Italy. 86pp.

FAO. (2007). State of the World's Forests 2001. Food and Agriculture Organization of the United

FAO. (2009). State of World's Forests. Rome, Italy. 152pp..

GBEP .(2008) A review of the current state of bioenergy development in G8 + 5 countries.FAO, Rome.

Geremew, K., Gedefaw, M., Dagnew, Z. and Jara, D., 2014. Current level and correlates of traditional cooking energy sources utilization in urban settings in the context of climate change and health, northwest Ethiopia: a case of Debre Markos town. BioMed research international, 2014.

Gerland, P., Raftery, A.E., Ševčíková, H., Li, N., Gu, D., Spoorenberg, T., Alkema, L., Fosdick, B.K., Chunn, J., Lalic, N. and Bay, G., 2014. World population stabilization unlikely this century. Science, 346(6206), pp.234237.

Githiomi, J.K. and Oduor, N., 2012. Strategies for sustainable wood fuel production in Kenya. 
Guta, D.D., 2012. Assessment of biomass fuel resource potential and utilization in Ethiopia: sourcing strategies for renewable energies. International Journal of Renewable Energy Research (IJRER), 2(1), pp.131-139.

Hartter, J. and Boston, K., 2007. An integrated approach to modeling resource utilization for rural communities in developing countries. Journal of Environmental Management, 85(1), pp.78-92.

Hiemstra-van der Horst, G. and Hovorka, A.J., 2009. Fuelwood: the "other" renewable energy source for Africa?. Biomass and bioenergy, 33(11), pp.1605-1616.

Hosier, R.H. and Kipondya, W., 1993. Urban household energy use in Tanzania: prices, substitutes and poverty. Energy Policy, 21(5), pp.454-473.

IEA 2002. World Energy outlook 2002. International Energy Agency, Paris.

IEA.( 2010).International Energy Agency "World Energy Outlook,"

Iiyama, M., Neufeldt, H., Dobie, P., Njenga, M., Ndegwa, G. and Jamnadass, R., 2014. The potential of agroforestry in the provision of sustainable woodfuel in sub-Saharan Africa. Current Opinion in Environmental Sustainability, 6, pp.138-147.

Ishengoma, R.C. and Nagoda, L., 1991. Solid Wood: Physical and Mechanical Properties, Defects, Grading and Utilization As Fuel. A teaching compendium for forest students. Faculty of Forestry and Nature Conservation, Sokoine University of Agriculture, Morogoro, Tanzania.

Jeuland, M.A. and Pattanayak, S.K., 2012. Benefits and costs of improved cookstoves: assessing the implications of variability in health, forest and climate impacts. PloS one, 7(2), p.e30338.

Johansson, T.B., Kelly, H., Reddy, A.K. and Williams, R.H., 1993. Renewable energy: sources for fuels and electricity.

Jones, B., 2015. Social and environmental impacts of charcoal production in Liberia (Doctoral dissertation).

Kaale, B.K., 1984, March. Sustained supply of wood energy in Tanzania (Five-year National Village Afforestation Plan). In Proceedings of a national seminar on wood-based energy for development in Tanzania (pp. 26-28).

Kaale, B.K., 1994. The search for alternative source of energy to woodfuel in Southern Africa. Forest Resources Management Project, Dar es Salaam. SADC Energy Sector TAU Angola.

Kabeer, N., 2003. Gender inequality in educational outcomes: a household perspective. Paper Commissioned for the EFA Global Monitoring Report, 4.

Kambewa, P. and Chiwaula, L., 2010. Biomass energy use in Malawi.

Kambewa, P., 2007. Charcoal--the Reality: A Study of Charcoal Consumption, Trade, and Production in Malawi (No. 21). Iied.

Kamfor, C., 2002. Biomass Energy survey for Households and small scale service establishments in Kenya.

Kammen, D. M. (1995b) "From energy efficiency to social utility: Improved cookstoves and the Small is Beautiful Model of development," in Energy as an instrument for socio-economic development.

Karekezi, S., 2002. Poverty and energy in Africa - a brief review. Energy Policy, 30(11-12), pp.915-919.

Karekezi, S., Lata, K. and Coelho, S.T., 2006. Traditional biomass energy: Improving its use and moving to modern energy use. Renewable Energy-A Global Review of Technologies, Policies and Markets, 1, pp.231261.

Kees, M. and Feldmann, L., 2011. The role of donor organisations in promoting energy efficient cook stoves. Energy Policy, 39(12), pp.7595-7599.

Köhlin, G., Sills, E.O., Pattanayak, S.K. and Wilfong, C., 2011. Energy, gender and development: what are the linkages? Where is the evidence?. The World Bank.

Kossove, D., 1982. Smoke-filled rooms and lower respiratory disease in infants. South African medical journal= Suid-Afrikaanse tydskrif vir geneeskunde, 61(17), pp.622-624.

Laxmi, V., Parikh, J., Karmakar, S. and Dabrase, P., 2003. Household energy, women's hardship and health impacts in rural Rajasthan, India: need for sustainable energy solutions. Energy for sustainable development, 7(1), pp.50-68.

Leach, G. (1992). “The Energy Transition.”Energy Policy 20(2): 116-123.Leap to Equalityll, UNESCO.

Legros, G., Havet, I., Bruce, N., Bonjour, S., Rijal, K., Takada, M. and Dora, C., 2009. The energy access situation in developing countries: a review focusing on the least developed countries and Sub-Saharan Africa. World Health Organization.

Lim, S.S., Vos, T., Flaxman, A.D., Danaei, G., Shibuya, K. and Adair-Rohani, H., 2010. al, e.(2012). A comparative risk assessment of burden of disease and injury attributable to 67 risk factors and risk factor clusters in 21 regions, 1990-2010: A systematic analysis for the Global Burden of Disease Study 2010. The Lancet, 380(9859), pp.2224-2260.

Lioy, P.J., 1990. Assessing total human exposure to contaminants. A multidisciplinary approach. Environmental science \& technology, 24(7), pp.938-945.

Liu, H., Jiang, G.M., Zhuang, H.Y. and Wang, K.J., 2008. Distribution, utilization structure and potential of biomass resources in rural China: with special references of crop residues. Renewable and sustainable energy reviews, 12(5), pp.1402-1418. 
Luoga, E.J., Witkowski, E.T.F. and Balkwill, K., 2000. Economics of charcoal production in miombo woodlands of eastern Tanzania: some hidden costs associated with commercialization of the resources. Ecological economics, 35(2), pp.243-257.

MacCarty, N., Still, D. and Ogle, D., 2010. Fuel use and emissions performance of fifty cooking stoves in the laboratory and related benchmarks of performance. Energy for Sustainable Development, 14(3), pp.161-171.

Maes, W.H. and Verbist, B., 2012. Increasing the sustainability of household cooking in developing countries: policy implications. Renewable and Sustainable Energy Reviews, 16(6), pp.4204-4221.

Makundi, W.R., 2001. Potential and cost of carbon sequestration in the Tanzanian forest sector. Mitigation and Adaptation Strategies for Global Change, 6(3-4), pp.335-353.

Mandelli, S., Barbieri, J., Mattarolo, L. and Colombo, E., 2014. Sustainable energy in Africa: A comprehensive data and policies review. Renewable and Sustainable Energy Reviews, 37, pp.656-686.

Mangi, J.K., 2011. Woodfuel consumption in Shinyanga rural district, Tanzania (Doctoral dissertation, Sokoine University of Agriculture (SUA)).

McCracken, J.P. and Smith, K.R., 1998. Emissions and efficiency of improved woodburning cookstoves in Highland Gatemala. Environment International, 24(7), pp.739-747.

Mekonnen, A. and Köhlin, G., 2008. Biomass fuel consumption and dung use as manure: evidence from rural households in the Amhara Region of Ethiopia. Environment for Development Discussion Paper-Resources for the Future (RFF), (08-17).

Mekonnen, A., 1997. Rural household fuel production and consumption in Ethiopia: A case study. Univ..

MoPD\&E, (2004), Candlelight for Health, Education \& Environment Case Study Impact of Charcoal Production on Environment and the Socio Economy of Pastoral communities of Somaliland.

Morris, K., Morganlander, M., Coulehan, J.L., Gahagen, S. and Arena, V.C., 1990. Wood-burning stoves and lower respiratory tract infection in American Indian children. American Journal of Diseases of Children, 144(1), pp.105-108.

Msuya, N., Masanya, E. and Temu, A.K., 2011. Environmental burden of charcoal production and use in Dar es Salaam, Tanzania.

Muchiri, L., 2008. Gender and equity in bioenergy access and delivery in Kenya. Practical Action East Africa.

Mugo, F. and Gathui, T., 2010. Biomass energy use in Kenya.

Murphy, J.T., 2001. Making the energy transition in rural East Africa: Is leapfrogging an alternative?. Technological Forecasting and Social Change, 68(2), pp.173-193.

Mwampamba, T.H., 2007. Has the woodfuel crisis returned? Urban charcoal consumption in Tanzania and its implications to present and future forest availability. Energy Policy, 35(8), pp.4221-4234.

Mwampamba, T.H., Ghilardi, A., Sander, K. and Chaix, K.J., 2013. Dispelling common misconceptions to improve attitudes and policy outlook on charcoal in developing countries. Energy for sustainable development, 17(2), pp.75-85.

Najam, A. and Cleveland, C.J., 2003. Energy and Sustainable Development at Global.

Nathan, H.S.K., Rampal, P. and Mishra, S., 2009. Gender Development Index: Two Corrections. Indira Gandhi Institute of Development, Mumbai.

Ncube M. (2012). Urbanization in Africa [Online]. Abidjan, Ivory Coast: African Development Bank Available: \pm http://www.afdb.org/en/blogs/afdb-championing-inclusive-growth-across-

Ng'andwe, P., Saramäki, K., Simfukwe, P., Chisha-Kasumu, E. and Korhonen, K., 2016. Sustainable Livelihoods in the Green Economy.

Njong, A.M. and Johannes, T.A., 2011. An analysis of domestic cooking energy choices in Cameroon. European Journal of Social Sciences, 20(2), pp.336-347.

Norboo, T., Yahya, M., Bruce, N.G., Heady, J.A. and Ball, K.P., 1991. Domestic pollution and respiratory illness in a Himalayan village. International Journal of Epidemiology, 20(3), pp.749-757.

Pachauri, S., 2004. An analysis of cross-sectional variations in total household energy requirements in India using micro survey data. Energy policy, 32(15), pp.1723-1735.

Potts, D., 2009. The slowing of sub-Saharan Africa's urbanization: evidence and implications for urban livelihoods. Environment and Urbanization, 21(1), pp.253-259.

Raman, P., Murali, J., Sakthivadivel, D. and Vigneswaran, V.S., 2013. Performance evaluation of three types of forced draft cook stoves using fuel wood and coconut shell. Biomass and bioenergy, 49, pp.333-340.

Ravindranath, N.H. and Hall, D.O., 1995. Biomass, energy and environment: a developing country perspective from India. Oxford University Press.

Ravindranath, N.H., Somashekar, H.I., Nagaraja, M.S., Sudha, P., Sangeetha, G., Bhattacharya, S.C. and Salam, P.A., 2005. Assessment of sustainable non-plantation biomass resources potential for energy in India. Biomass and Bioenergy, 29(3), pp.178-190.

Reddy, B.S. and Nathan, H.S.K., 2013. Energy in the development strategy of Indian households-the missing half. Renewable and Sustainable Energy Reviews, 18, pp.203-210. 
Reddy, B.S. and Srinivas, T., 2009. Energy use in Indian household sector-An actor-oriented approach. Energy, 34(8), pp.992-1002.

Reddy, C.S. and Manak, S., 2005. Self-help groups: A keystone of microfinance in India-women empowerment and social security. Andhra Pradesh Mahila Abhivruddhi Society (APMAS). India: Hyderabad.

Robin, L.F., Lees, P.S., Winget, M., Steinhoff, M., Moulton, L.H., Santosham, M. and Correa, A., 1996. Woodburning stoves and lower respiratory illnesses in Navajo children. The Pediatric infectious disease journal, 15(10), pp.859-865.

Sathaye, J. and Meyers. S. (1994). Energy use in developing countries: a review. In: Energy Research in Developing Countries (Edited by Grahams, S). Amrican Council of Energy, Washington DC. pp. 17-19.

Seager, J. and Hartmann, B., 2005. Mainstreaming gender in environmental assessment and early warning. United Nations Environment Programme.

Shrimali, G., Slaski, X., Thurber, M.C. and Zerriffi, H., 2011. Improved stoves in India: A study of sustainable business models. Energy Policy, 39(12), pp.7543-7556.

Sivan Kartha,(2006) 2020 World Vision For Food And Agriculture And Environment

Smith, K.R., 1993. Fuel combustion, air pollution exposure, and health: the situation in developing countries. Annual Review of Energy and the Environment, 18(1), pp.529-566.

Smith, K.R., 1993. Fuel combustion, air pollution exposure, and health: the situation in developing countries. Annual Review of Energy and the Environment, 18(1), pp.529-566.

Smith, K.R., 2002. Indoor air pollution in developing countries: recommendations for research. Indoor air, 12(3), pp.198-207.

Smith, K.R., 2013. Biofuels, air pollution, and health: a global review. Springer Science \& Business Media.

Smith, K.R., Apte, M.G., Yuqing, M., Wongsekiarttirat, W. and Kulkarni, A., 1994. Air pollution and the energy ladder in Asian cities. Energy, 19(5), pp.587-600.

Sosovele, H., 2010. Policy challenges related to biofuel development in Tanzania. Africa Spectrum, 45(1), pp.117129.

Soussan, J. (1998). Primary Resources and Energy in Third World. Earthscan, Routedge; London. 54pp.

Steierer, B.F., 2011. Highlights on wood charcoal: 2004-2009. Wood Energy, FAOSTAT-ForesSTAT. Rome: FAO Forestry Department, pp.1-3.

Stotsky, M.J.G., 2006. Gender and its relevance to macroeconomic policy: A survey (No. 6-233). International Monetary Fund.

T.B. and Goldemberg, J. (eds.), Energy for Sustainable Development: A Policy Agenda, pp. 115-136. New York: United Nations Development Programme.

TERI. (2010). Biomass energy in India. A background paper prepared for the International Institute for Environment and Development (IIED) for an international ESPA workshop on biomass energy, 19-21 October 2010, Parliament House Hotel, Edinburgh. TERI, New Dehli, India. the Challenge of Sustainability, New York: UNDP.

UNDP .(2004). "World Energy Assessment, United Nations Development Programme, New York,

UNDP. (2007). United Nations Development Programme Energizing Poverty Reduction: A Review of the EnergyPoverty Nexus in Poverty Reduction Strategy Papers. New York.

UNDP.( 2000). (United Nations Development Program), World Energy Assessment: Energy and

UNDP.( 2001). (United Nations Development Program), Generating opportunities, Case studies on energy and women, UNDP Sustainable Energy, 2001, New York: UNDP.

United Nations. (2013b). World Population Prospects: The 2012 Revision; Highlights and Advanced Tables. Working paper No ESA/P/WP228, New York, USA: Department of Economic and Social Affairs Population Division United Nations, p. 78

United States Environmental Protection Agency.( 1997). Revisions to the National Ambient Air Quality Standards for Particles Matter. Federal Register, July 18, 62: 38651-38701.

Urmee, T. and Gyamfi, S., 2014. A review of improved Cookstove technologies and programs. Renewable and Sustainable Energy Reviews, 33, pp.625-635.

WHO. (1995) . World Health Report. Geneva, World Health Organization.

WHO. (2006). World Health Organization, "Fuel for Life: Household Energy and Health". Geneva.

WHO. (2007). World Health Organization ,Indoor air pollution: National burden of disease estimates. Geneva, Switzerland: WHO Press.

World Bank .(2000). Africa Development Indicators: Washington D.C., The World Bank.

World Health Organization (WHO) (2000).Air quality guidelines for Europe. Copenhagen, World Health Organization Regional Office for Europe, (in press). 